\title{
THE EFFECT OF ADDITION CURCUMA'S (Curcuma Xanthorrhiza Roxb) EXTRACT TO THE INCREASE OF FEED CONSUMPTION, EFFICIENCY AND THE GROWTH OF CATFISH (Pangasius)
}

\author{
Prastito $^{1}$ - Pinandoyo $^{1}$ - Ristiawan Agung Nugroho ${ }^{1}$. Vivi \\ Endar Herawati ${ }^{1}$
}

Ringkasan Catfish (Pangasius sp.) Is one of the most cultivated freshwater fish, because it is one of the fish that has a high economic value. However, the use of phytopharmaca is used to improve feed efficiency and fish growth. One of the phytopharmaca which can be used as an antimicrobial is temulawak (Curcuma xanthorrhiza Roxb). This study aims to determine the optimal dose of the effect of temulawak extract on artificial feed in increasing feed consumption, efficiency of feed utilization, and growth rate of catfish (Pangasius sp.). The test fish is maintained with a stocking density of 1 tail / l with a maintenance time of 42 days. This study used an experimental method with 4 treatments and 3 replications. The treatments in this study were Treatment A (addition of $0 \mathrm{ml}$ ginger extract), $B$ (addition of $6 \mathrm{ml}$ temulawak extract), $C$ (addition of $12 \mathrm{ml}$ curcuma extract), and $\mathrm{D}$ (addition of $18 \mathrm{ml}$ ginger extract). The data observed included absolute weight, crime scene, EPP, SGR, REP, SR

\footnotetext{
$\left.{ }^{1}\right)$ Departemen Akuakultur Jurusan Perikanan Fakultas Perikanan dan Ilmu Kelautan, Universitas Diponegoro J1. Prof. Soedarto, SH, Tembalang, Semarang, Jawa Tengah -50275 , Telp/Fax. +6224 7474698 E-mail: pinandjaya@yahoo.com
}

and water quality. The results showed that the addition of temulawak extract to artificial feed had a very significant effect on absolute weights, crime scenes, EPP, SGR, REP but did not differ significantly for survival. The optimum dose of addition of curcuma extract to total feed consumption is $11 \mathrm{ml} \mathrm{capa-}$ ble of producing a maximum crime scene of $168.1 \mathrm{~g}$, efficiency of feed utilization is $10.5 \mathrm{ml}$ capable of producing a maximum EPP of $70.3 \%$ and specific growth rate is $10.8 \mathrm{ml}$ resulting in $\mathrm{ma}$ ximum SGR $2.46 \%$ / day.

Keywords masin, lactic acid bacteria, fermentation, bacteriocin, protease

Received : 24 Agustus 2018

Accepted : 23 September 2018

\section{PENDAHULUAN}

Ikan patin adalah salah satu ikan air tawar yang paling banyak dibudidayakan, karena merupakan salah satu ikan yang memiliki nilai ekonomis yang cukup tinggi. Di samping itu, patin mengandung protein yang tinggi dan kolesterol yang rendah. Budidaya ikan patin 
tidak terlalu sulit karena ikan patin toleran dangan kandungan oksigen yang relatif rendah dan merupakan pemakan segala atau omnivora (Ananda et al., 2015).

Beberapa upaya yang dilakukan untuk mengefisienkan pemberian pakan dan meningkatkan pertumbuhan salah satunya dengan menambahkan suplement pada pakan. Manfaat yang diperoleh dengan pemberian suplemen diantaranya meningkatkan daya tahan tubuh terhadap serangan penyakit, melancarkan sistem pencernaan, menghemat dalam penggunaan pakan dan meningkatkan nafsu makan ikan (Puspitasari, 2018).

Salah satu fitofarmaka yang bisa dijadikan sebagai antimikrobial adalah temulawak (C. xanthorrhiza Roxb). Rimpang temulawak mengandung zat berwarna kuning (kurkumin), serat, pati, kalium oksalat, minyak atsiri, dan flavonida, zat-zat tersebut berfungsi sebagai antimikroba/antibakteri, mencegah penggumpalan darah, anti peradangan, melancarkan metabolisme dan fungsi organ tubuh (Ditjen, 2000).

Tujuan dari penelitian ini adalah untuk mengetahui dosis yang optimal pengaruh ekstrak temulawak pada pakan buatan dalam peningkatan konsumsi pakan, efisiensi pemanfaatan pakan, dan laju pertumbuhan ikan patin. Hasil penelitian ini diharapkan dapat memberikan informasi dan gambaran mengenai salah satu alternatif untuk meningkatkan konsumsi pakan ikan patin melalui penambahan ekstrak temulawak. Penelitian ini dilaksanakan pada bulan Mei hingga Juli 2017 yang bertempat di UPTD Balai Benih Ikan Cangkiran, Semarang, Jawa Tengah

\section{MATERI DAN METODE}

Ikan yang digunakan dalam penelitian ini adalah ikan patin Siam yang bobot awal rata-rata 4,36 $\pm 0,19$ gram/ekor pada stadia benih. Padat tebar setiap wadah 1 ekor / L dilakukan berdasarkan penelitian Ananda et al.,(2015). Wadah pemeliharaan yang digunakan dalam penelitian ini adalah bak plastik dengan ukuran 24 L. Sebanyak 12 buah bak plastik sebagai wadah pemeliharaan dan diisi air sebanyak $15 \mathrm{~L}$. Bak tersebut ditutup dengan waring supaya ikan uji tidak keluar. Penelitian ini menggunakan metode eksperimental Rancangan Acak Lengkap (RAL). Penelitian ini menggunakan 4 perlakuan dan 3 kali pengulangan. Perlakuan dalam penelitian ini adalah kombinasi penambahan ekstrak temulawak pada pakan dengan dosis yang berbeda yaitu: perlakuan A (pakan uji dengan penambahan ekstrak temulawak dengan dosis $0 \mathrm{ml}$ ), perlakuan $\mathrm{B}$ (pakan uji dengan penambahan ekstrak temulawak dengan dosis $6 \mathrm{ml}$ ), perlakuan $\mathrm{C}$ (pakan uji dengan penambahan ekstrak temulawak dengan dosis $12 \mathrm{ml}$ ), dan perlakuan D (pakan uji dengan penambahan ekstrak temulawak dengan dosis $18 \mathrm{ml}$ ). Pemeliharaan Ikan Patin dilakukan selama 42 hari.

Tahapan yang dilakukan sebelum menambahkan ekstrak temulawak ke pakan buatan yaitu pembuatan larutan ekstrak temulawak. Temulawak yang digunakan untuk pembuatan ekstrak temulawak yaitu sebanyak 250 gram. Proses pembuatan ekstrak temulawak menggunakan metode maserasi atau perendaman selama 2 x 24 jam yang dicampur dengan etanol $70 \%$. Proses pencampuran ekstrak temulawak dengan pakan menggunakan metode penyemprot- 
an atau sprayer. Ekstrak temulawak dicampur terlebih dahulu dengan aquadest. Setelah dilakukan pencampuran ekstrak temulawak dengan aquadest, pakan uji langsung disemprot dengan larutan ekstrak temulawak hingga merata dan di angin-anginkan agar pakan tidak berjamur. Pemberian pakan dilakukan sebanyak 3 kali sehari yakni pada pukul 08.00 WIB, 12.00 WIB, dan 16.00 WIB. Jumlah pakan yang diberikan per wadah yaitu $5 \%$ dari bobot ikan.

Perhitungan pertumbuhan bobot mutlak dihitung dengan menggunakan rumus Takeuchi (1988), sebagai berikut

$W=W_{t}-W_{0}$

dimana $\mathrm{W}$ adalah pertambahan bobot mutlak $(\mathrm{g}) ; \mathrm{W}_{0}$ adalah bobot awal ikan uji (gram); dan $\mathrm{W}_{t}$ adalah bobot akhir ikan uji (gram)

Perhitungan total konsumsi pakan digunakan rumus berdasarkan Pereira et al. (2007), sebagai berikut :

$T K P=F 1-F 2$

dimana, (TKP) Total konsumsi pakan, (gram); (F1) Jumlah pakan awal (gram); (F2)Jumlah pakan akhir (gram)

Perhitungan nilai efisiensi pemanfaatan pakan dihitung dengan menggunakan rumus Tacon (1987), sebagai berikut :

$E P P=\frac{W_{t}-W_{0}}{F} \times 100 \%$

dimana, (EPP) Efisiensi pemanfaatan pakan $(\%) ;\left(\mathrm{W}_{t}\right)$ Bobot total hewan uji pada akhir penelitian (gram); $\left(\mathrm{W}_{o}\right)$ Bobot total hewan uji pada awal penelitian (gram); dan (F) Jumlah pakan yang dikonsumsi selama penelitian (gram).

Menurut Takeuchi (1988), laju pertumbuhan harian (Survival Growth Rate) ikan dihitung dengan menggunakan rumus:

$S G R=\frac{W_{t}-W_{0}}{W_{0 x} t} \times 100 \%$

dimana SGR (Laju pertumbuhan Harian, $\%$ per hari) $; \mathrm{W}_{t}$ (Bobot total ikan pada akhir pemeliharaan, gram); $\mathrm{W}_{o}$ (Bobot total ikan pada awal pemeliharaan, gram); dan t (Waktu pemeliharaan, hari)

Perhitungan rasio efisiensi protein menggunakan rumus Tacon (1987)):

$G R=\frac{W_{t}-W_{0}}{P_{i}} \times 100 \%$

dimana PER (Rasio Efisiensi Protein, $\%$ ); $\mathrm{W}_{t}$ (Biomassa ikan uji pada akhir penelitian, gram); $\mathrm{W}_{0}$ (Biomassa ikan uji pada awal penelitian, gram); dan Pi (Berat pakan yang dikonsumsi $\mathrm{x} \%$ protein pakan).

\section{HASIL DAN PEMBAHASAN}

Hasil penelitian pengaruh penambahan ekstrak temulawak pada pakan terhadap peningkatan konsumsi pakan, efisiensi pemanfaatan pakan, dan pertumbuhan meliputi nilai W, TKP, EPP, SGR, REP; dan SR. Berdasarkan data pertumbuhan bobot mutlak total konsumsi pakan, efisiensi pemanfaatan pakan, laju pertumbuhan spesifik, protein efisiensi rasio dan kelulushidupan pada ikan patin selama pemeliharaan dapat dibuat tabel 1 . 
Tabel 1 Hasil analisis data selama penelitian

\begin{tabular}{|c|c|c|c|c|}
\hline \multirow{2}{*}{ Variabel Data } & \multicolumn{4}{|c|}{ Perlakuan } \\
\hline & $\mathrm{A}$ & $\bar{B}$ & $\mathrm{C}$ & $\mathrm{D}$ \\
\hline Bobot Mutlak (g) & $60,57 \pm 2,89^{d}$ & $116,12 \pm 2,82^{a}$ & $107,33 \pm 2,32^{b}$ & $93,29 \pm 2,18^{c}$ \\
\hline $\mathrm{TKP}(\mathrm{g})$ & $131,39 \pm 2,49^{d}$ & $166,67 \pm 0,93^{a}$ & $162,06 \pm 1,79^{b}$ & $155,94 \pm 1,40^{c}$ \\
\hline $\operatorname{EPP}(\%)$ & $46,14 \pm 3,08^{c}$ & $69,97 \pm 1,54^{a}$ & $66,23 \pm 0,69^{a}$ & $59,83 \pm 1,66^{b}$ \\
\hline SGR (\%/hari) & $1,56 \pm 0,06^{d}$ & $2,43 \pm 0,04^{a}$ & $2,31 \pm 0,04^{b}$ & $2,12 \pm 0,03^{c}$ \\
\hline $\operatorname{PER}(\%)$ & $1,09 \pm 0,05^{d}$ & $2,06 \pm 0,05^{a}$ & $1,90 \pm 0,04^{b}$ & $1,68 \pm 0,04^{c}$ \\
\hline $\operatorname{SR}(\%)$ & $88,89 \pm 3,85^{a}$ & $97,78 \pm 3,85^{a}$ & $95,56 \pm 7,70^{a}$ & $91,11 \pm 3,85^{a}$ \\
\hline
\end{tabular}

Berdasarkan hasil analisis ragam yang telah dilakukan menunjukkan bahwa penambahan ekstrak temulawak pada pakan buatan memberikan pengaruh nyata $(\mathrm{P}<0,05)$ terhadap pertumbuhan bobot mutlak dan laju pertumbuhan spesifik ikan patin. Pertumbuhan bobot mutlak disebabkan karena temulawak memiliki kandungan antibakteri yang dapat melisiskan racun yang menempel pada dinding usus, sehingga penyerapan zat nutrisi menjadi lebih baik dan dapat memicu pertumbuhan.

Hasil analisis uji duncan didapatkan perlakuan tertinggi pada pertumbuhan bobot mutlak adalah perlakuan dengan penambahan ekstrak temulawak $6 \mathrm{ml} / \mathrm{kg}$ pakan, yang kedua perlakuan $\mathrm{C}$ dengan penambahan ekstrak temulawak $12 \mathrm{ml} / \mathrm{kg}$ pakan sebesar, perlakuan D dengan penambahan ekstrak temulawak $18 \mathrm{ml} / \mathrm{kg}$ pakan sebesar dan terendah adalah perlakuan A dengan penambahan ekstrak temulawak $0 \mathrm{ml} / \mathrm{kg}$ pakan sebesar. Perlakuan B mendapatkan nilai pertumbuhan bobot mutlak yang tertinggi yaitu sebesar 8,03 $\pm 0,35$ g. Hal ini diduga karena temulawak memiliki fungsi sebagai imunostimulan secara tidak langsung yang dimana prosesnya berasal dari pemberian pakan yang telah dicampur dengan ekstrak temulawak. Pertumbuhan bobot mutlak terendah pada perlakuan $12 \mathrm{ml}$ dan $18 \mathrm{ml}$ diperoleh nilai rata-rata 7,25 $\pm 0,53 \mathrm{~g}$ dan 6,77 $\pm 0,05$ g. Hal ini diduga karena dosis ekstrak temulawak yang diberikan cukup berlebihan sehingga menyebabkan pertumbuhan bobot yang kurang maksimal. Menurut Insana and Wahyu (2015)bahwa semakin besar dosis temulawak yang diberikan maka akan menyebabkan pertumbuhan yang tidak stabil.

Penambahan ekstrak temulawak pada pakan buatan mempunyai berbagai manfaat bagi tubuh ikan terutama untuk imunostimulan dan pertumbuhan bobot mutlak. Hal ini diduga karena temulawak mengandung senyawa kurkumin. Fungsi dari kurkumin yaitu sebagai pemacu pertumbuhan yang ditandai dengan meningkatkanya nafsu makan pada ikan. Menurut (Purwati and Fitriliyani, 2016), meningkatnya pertumbuhan didukung dengan kesehatan yang baik pada ikan dan akan meningkatkan efisiensi penyerapan zat makanan untuk memenuhi kebutuhan hidup dan produksi yang ditunjukkan dengan pertambahan bobot. Penambahan ekstrak temulawak pada pakan buatan mempunyai berbagai manfaat bagi tubuh ikan terutama untuk imunostimulan dan pertumbuhan bobot mutlak.

Dosis optimum ekstrak temulawak pada pertumbuhan bobot mutlak ikan patin diketahui dengan cara melakukan uji Polinomial Orthogonal. Uji Polinomial Orthogonal pada pertumbuhan bo- 
bot mutlak diperoleh hubungan yang berpola kuadratik $(\mathrm{y}=-0,4833 \mathrm{x} 2+10,19 \mathrm{x}$ $+63,521)$ dan $\mathrm{R} 2=0,89$. Titik optimum pada perlakuan B (pemberian ekstrak temulawak $6 \mathrm{ml}$ ) didapatkan dosis ekstrak temulawak optimal yang didapat dari persamaan tersebut yaitu 10,5 ml mampu menghasilkan pertumbuhan bobot mutlak maksimal 117,23 g. Nilai $R^{2}$ menunjukkan bahwa $89 \%$ pertumbuhan bobot mutlak dipengaruhi oleh pemberian ekstrak temulawak dalam pakan buatan ikan patin .

Berdasarkan hasil analisa ragam menunjukkan bahwa perbedaan pemberian frekuensi pakan itu berpengaruh nyata $(\mathrm{P}<0,05)$ terhadap total konsumsi pakan ikan patin. Total konsumsi pakan yang tertinggi adalah perlakuan dengan dosis $6 \mathrm{ml}$ (Perlakuan B) menghasilkan nilai total konsumsi pakan tinggi dikarenakan frekuensi pakan yang dihasilkan oleh perlakuan dosis $6 \mathrm{ml}$ (perlakuan B) lebih tinggi dibandingkan dengan perlakuan tanpa penambahan ekstrak temulawak, perlakuan dosis $12 \mathrm{ml}$ (perlakuan C) dan perlakuan dosis $18 \mathrm{ml}$ (perlakuan D). Hal ini diduga temulawak memiliki fungsi untuk meningkatkan nafsu makan pada ikan patin. Menurut Noviana et al. (2014), bahwa proses makan pada ikan dimulai dari tingkat konsumsi nafsu makan, kemudian dilanjutkan dengan respon terhadap rangsangan dan pencarian sumber rangsangan, menentukan lokasi, jenis pakan dan penangkapan pakan.

Perlakuan dosis $6 \mathrm{ml}$ (perlakuan B) merupakan perlakuan yang menghasilkan nilai total konsumsi pakan tertinggi yaitu $166,67 \pm 0,93$ gr. Berdasarkan dari hasil tersebut maka banyaknya pemberian pakan untuk ikan patin dapat mem- pengaruhi kebutuhan pakan ikan dan laju pertumbuhan pada ikan patin. Pengaruh penambahan ekstrak temulawak pada pakan mampu memberikan pengaruh nyata terhadap total konsumsi pakan. Hal tersebut diduga karena ekstrak temulawak memiliki kandungan kurkumin yang fungsinya sebagai imunostimulan. Menurut Manoppo and Kolopita (2016), imunostimulan memiliki peran sebagai penjaga sistem kekebalan tubuh sehingga dapat memacu peningkatan konsumsi pakan pada ikan.

Dosis optimum ekstrak temulawak pada total konsumsi pakan ikan patin diketahui dengan cara melakukan uji Polinomial Orthogonal. Uji Polinomial Orthogonal pada pertumbuhan bobot mutlak diperoleh hubungan yang berpola kuadratik $(\mathrm{y}=-0,2875 \mathrm{x} 2+6,3251 \mathrm{x}+$ 133,31) dan $\mathrm{R}^{2}=0,89$. Titik optimum pada perlakuan $\mathrm{B}$ (pemberian ekstrak temulawak $6 \mathrm{ml}$ ) didapatkan dosis ekstrak temulawak optimal yang didapat dari persamaan tersebut yaitu $11 \%$ mampu menghasilkan total konsumsi pakan maksimal 168,1 g. Nilai $\mathrm{R}^{2}$ menunjukkan bahwa $89 \%$ total konsumsi pakan dipengaruhi oleh pemberian ekstrak temulawak dalam pakan buatan ikan patin .

Berdasarkan hasil penelitian menunjukkan bahwa penambahan ekstrak temulawak pada pakan buatan terdapat interaksi $(\mathrm{P}<0,05)$ terhadap efisiensi pemanfaatan pakan (EPP) ikan patin. Hasil tersebut menunjukkan bahwa efisiensi pemanfaatan pakan pada ikan patin dipengaruhi oleh adanya kandungan kurkumin yang memiliki pengaruh nyata dalam memanfaatkan pakan. Setelah dilakukan uji Duncan bahwa perlakuan yang tertinggi pada efisiensi pemanfaatan pakan $(\mathrm{EPP})(\mathrm{P}<0,05)$ ada- 
lah perlakuan $\mathrm{B}$ dengan penambahan ekstrak temulawak sebanyak $6 \mathrm{ml} / \mathrm{kg}$ pakan sebesar $69,67 \pm 1,54 \%$. Nilai efisiensi pemanfaatan pakan (EPP) yang terendah pada perlakuan A dengan penambahan ekstrak temulawak sebanyak $0 \%$ pakan sebesar $46,14 \pm 3,08 \%$. Hal tersebut diduga karena pengaruh zat imunostimulan yang terdapat pada temulawak berperan dalam meminimalisir stress lingkungan pada ikan patin sehingga dapat berpengaruh terhadap pemanfatan pakannnya. Hal ini sesuai dengan penelitian Wong et al. (2013) yang membuktikan bahwa pemberian pakan buatan dengan tambahan Sargassum cristaefokium $2 \mathrm{~g} / \mathrm{kg}$ pakan pada ikan kerapu muara (E. coides) selama 9 hari dapat meningkatkan sistem kekebalan tubuh terhadap bakteri Streptococcus sp. dan nilai efisiensi pemanfaatan pakan.

Dosis optimum ekstrak temulawak pada efisiensi pemanfaatan pakan ikan patin diketahui dengan cara melakukan uji Polinomial Orthogonal. Uji Polinomial Orthogonal pada pertumbuhan bobot mutlak diperoleh hubungan yang berpola kuadratik $(\mathrm{y}=-0,2079 \mathrm{x} 2+4,3702 \mathrm{x}$ $+47,335)$ dan $\mathrm{R}^{2}=0,88$. Titik optimum pada perlakuan B (pemberian ekstrak temulawak $6 \mathrm{ml}$ ) didapatkan dosis ekstrak temulawak optimal yang didapat dari persamaan tersebut yaitu 10,5\% mampu menghasilkan efisiensi pemanfaatan pakan maksimal $70,30 \%$. Nilai $\mathrm{R}^{2}$ menunjukkan bahwa $88 \%$ efisiensi pemanfaatan pakan dipengaruhi oleh pemberian ekstrak temulawak dalam pakan buatan ikan patin .

Ikan patin yang dipelihara selama penelitian mengalami pertambahan bobot dan panjang. Laju pertumbuhan spesifik berfungsi untuk menghitung persentase pertumbuhan berat ikan per hari.
Berdasarkan dari hasil analisis ragam $(\mathrm{P}>0,05)$ nilai SGR menunjukkan bahwa pemberian pakan campuran ekstrak temulawak dengan dosis yang berbeda memberikan pengaruh yang sangat nyata pada ikan patin. Pengaruh tersebut diduga karena kandungan nutrisi di dalam pakan digunakan sebagian besar untuk pertumbuhan ikan patin . Menurut Insana and Wahyu (2015), bahwa perbedaan nilai laju pertumbuhan disebabkan oleh kandungan jumlah dosis temulawak yang diberikan. Perbedaan dosis temulawak yang diberikan berpengaruh terhadap peningkatan konsumsi pakan dan efisiensi pemanfaatan pakan.

Perlakuan dosis $6 \mathrm{ml}$ merupakan perlakuan yang menghasilkan nilai SGR yaitu $2,43 \pm 0,04$. Perlakuan dosis $12 \mathrm{ml}$ menghasilkan nilai SGR yaitu 2,31 $\pm 0,04$. Perlakuan dosis $18 \mathrm{ml}$ menghasilkan nilai SGR yaitu 2,12 $\pm 0,03$. Perlakuan tanpa dosis menghasilkan nilai SGR terendah yaitu $1,56 \pm 0,06$. Nilai SGR tertinggi yaitu pada perlakuan dosis $6 \mathrm{ml}$, hal ini menunjukkan bahwa pertumbuhan berkaitan dengan frekuensi pakan yang diberikan. Nilai SGR tertinggi kedua dan ketiga yaitu pada perlakuan dosis 12 dan $18 \mathrm{ml}$, hal ini diduga karena pengaruh dosis temulawak yang terlalu tinggi yang menyebabkan nutrisi pada pakan mudah hilang sehingga dapat mengganggu organ pencernaan pada ikan. Sedangkan nilai SGR terendah yaitu pada perlakuan tanpa dosis temulawak, hal ini diduga karena pakan yang diberikan pada perlakuan tanpa dosis temulawak tidak terdapat ekstrak temulawak yang menyebabkan efisiensi pemanfaatan pakan dan nafsu makan ikan menurun. Menurut Mulyadi et al. (2010), bahwa Kekurangan ma- 
kanan dan energi yang dibutuhkan dapat mengakibatkan kekurangan pertumbuhan karena energi digunakan untuk memelihara fungsi tubuh dan pergerakan.

Pengaruh Penambahan ekstrak temulawak pada pakan buatan mampu memberikan pengaruh yang nyata terhadap laju pertumbuhan spesifik. Hal ini diduga karena pengaruh kandungan kurkumin dari temulawak. Kandungan kurkumin pada temulawak selain berfungsi sebagai imunostimulan, juga untuk meningkatkan daya cerna dan sebagai penunjang pertumbuhan. Menurut Purwati and Fitriliyani (2016), laju pertumbuhan dipengaruhi oleh makanan, kepadatan, keturunan dan kecepatan pertumbuhan bobot mutlak.

Dosis optimum ekstrak temulawak pada laju pertumbuhan spesifik ikan patin diketahui dengan cara melakukan uji Polinomial Orthogonal. Uji Polinomial Orthogonal pada pertumbuhan bobot mutlak diperoleh hubungan yang berpola kuadratik $(y=-0,0073 \times 2+0,1582 x$ $+1,6069)$ dan $\mathrm{R} 2=0,89$. Titik optimum pada perlakuan B (pemberian ekstrak temulawak $6 \mathrm{ml}$ ) didapatkan dosis ekstrak temulawak optimal yang didapat dari persamaan tersebut yaitu $10,8 \mathrm{ml}$ mampu menghasilkan laju pertumbuhan spesifik maksimal $2,46 \%$ /hari. Nilai $\mathrm{R}^{2}$ menunjukkan bahwa $89 \%$ laju pertumbuhan spesifik dipengaruhi oleh pemberian ekstrak temulawak dalam pakan buatan ikan patin .

Berdasarkan hasil penelitian menunjukkan bahwa pemberian ekstrak temulawak pada pakan buatan terdapat interaksi $(\mathrm{P}<0,05)$ terhadap rasio efisiensi protein (REP) ikan patin . Hal tersebut menunjukkan bahwa rasio efisiensi protein pada ikan patin dapat di- pengaruhi adanya perbedaan taraf pada setiap dosis faktor. Setelah dilakukan uji Duncan perlakuan yang tertinggi pada REP adalah perlakuan B dengan penambahan ekstrak temulawak.

Rasio efisiensi protein (REP) terbaik yaitu pada perlakuan $B$ hal tersebut diduga menjadi salah satu dosis yang tepat untuk ikan patin. Hal ini diduga dosis temulawak yang diberikan mampu mengefisienkan pakan khususnya protein cell dengan enzim protease. Sedangkan nilai rasio efisiensi protein pada perlakuan $\mathrm{C}$ dan $\mathrm{D}$ di nilai kurang baik. Hal ini dikarenakan dosis dari ekstrak temulawak tidak mampu mengefisienkan pakan khususnya dari protein cell dengan enzim protease. Menurut Marzuqi et al. (2012), pemberian pakan yang memiliki kadar protein lebih tinggi,semakin banyak protein pada pakan yang dipergunakan oleh ikan untuk pertumbuhannya. Akibatnya pertambahan berat tubuh ikan semakin tinggi.b) sebanyak $6 \mathrm{ml} / \mathrm{kg}$ pakan sebesar 2,06 $\pm 0,05$ dibandingkan dengan perlakuan lainnya. Menurut Pratama et al. (2015), bahwa pakan yang berkualitas adalah pakan yang memiliki kandungan nutrisi yang lengkap dan seimbang sesuai dengan kebutuhan ikan, serta memiliki kandungan energi total yang optimum untuk menunjang pertumbuhan yang maksimum pada ikan tersebut.

Dosis optimum ekstrak temulawak pada rasio efisiensi protein ikan patin diketahui dengan cara melakukan uji Polinomial Orthogonal. Uji Polinomial Orthogonal pada pertumbuhan bobot mutlak diperoleh hubungan yang berpola kuadratik $(\mathrm{y}=-0,0083 \times 2+0,1767 \mathrm{x}+1,1446)$ dan $R^{2}=0,88$. Titik optimum pada perlakuan B (pemberian ekstrak temulawak $6 \mathrm{ml}$ ) didapatkan dosis ekstrak te- 
mulawak optimal yang didapat dari persamaan tersebut yaitu 10,6 ml mampu menghasilkan rasio efisiensi protein maksimal $2,08 \%$. Nilai $\mathrm{R}^{2}$ menunjukkan bahwa $88 \%$ rasio efisiensi protein dipengaruhi oleh pemberian ekstrak temulawak dalam pakan buatan ikan patin

Berdasarkan hasil analisis ragam menunjukkan bahwa penambahan ekstrak temulawak pada pakan buatan ikan patin tidak berpengaruh nyata $(\mathrm{P}>0,05)$ terhadap tingkat kelulushidupan. Nilai rata-rata kelulushidupan tertinggi adalah perlakuan B sebesar 97,78 $\pm 3,85 \%$ dan adapun nilai terendah adalah perlakuan A 88,89 $\pm 3,85 \%$. Secara statistik nilai kelulushidupan dari perlakuan A, perlakuan B, perlakuan C dan perlakuan D tidak ada yang lebih baik. Menurut Handayani et al. (2015), bahwa tingginya kelulushidupan ikan uji disebabkan karena kualitas air yang digunakan masih dalam batas toleransi sehingga mendukung untuk pemeliharaan ikan.

\section{SIMPULAN}

Kesimpulan yang didapat dari penelitian "Pengaruh Penambahan Ekstrak Temulawak Terhadap Peningkatan Konsumsi Pakan, Efisiensi Pemanfaatan Pakan, dan Pertumbuhan Ikan Patin " adalah Dosis optimum dari penambahan ekstrak temulawak terhadap total konsumsi pakan adalah $11 \mathrm{ml}$ mampu menghasilkan TKP maksimal 168,1 g, efsiensi pemanfaatan pakan adalah $10,5 \mathrm{ml}$ mampu menghasilkan EPP maksimal $70,3 \%$ dan laju pertumbuhan spesifik adalah 10,8 ml menghasilkan SGR maksimal 2,46\%/hari.
Acknowledgements Terima kasih penulis ucapkan kepada kepala UPTD Cangkiran Semarang yang telah menyediakan tempat dan fasilitas untuk pelaksanaan penelitian ini dan semua pihak yang telah membantu kelancaran penelitian ini.

\section{Pustaka}

Ananda, T., Rachmawati, D., and Samidjan, I. (2015). Pengaruh papain pada pakan buatan terhadap pertumbuhan ikan patin (pangasius hypopthalmus). Journal of Aquaculture Management and Technology, 4(1):47-53.

Ditjen, P. (2000). Parameter standar umum larutan tumbuhan obat. cetakan pertama. Depkes RI. Jakarta. Hal, pages 13-31.

Handayani, I., Nofyan, E., and Wijayanti, M. (2015). Optimasi tingkat pemberian pakan buatan terhadap pertumbuhan dan kelangsungan hidup ikan patin jambal (pangasius djambal). Jurnal Akuakultur Rawa Indonesia, 2(2):175-187.

Insana, N. and Wahyu, F. (2015). Subtitusi tepung temulawak (curcuma xanthorhiza sp) pada pakan dengan dosis berbeda terhadap pertumbuhan dan sintasan benih ikan nila (oreochromis niloticus). OCTOPUS: JURNAL ILMU PERIKANAN, 4(2):381-391.

Manoppo, H. and Kolopita, M. E. (2016). Penggunaan ragi roti (saccharomyces cerevisiae) sebagai imunostimulan untuk meningkatkan resistensi ikan mas (cyprinus carpio 1) terhadap infeksi bakteri aeromonas hydrophila. e-Journal BUDIDAYA PERAIRAN, 4(3).

Marzuqi, M., Astuti, N. W. W., and Suwirya, K. (2012). Pengaruh kadar protein dan rasio pemberian pakan terhadap pertumbuhan ikan kera- 
pu macan (epinephelus fuscoguttatus). Jurnal Ilmu dan Teknologi Kelautan Tropis, 4(1):55-65.

Mulyadi, Usman, and Suryani (2010). Pengaruh frekuensi pemberian pakan yang berbeda terhadap pertumbuhan dan kelulushidupan benih ikan silais (ompok hypophthalmus). berkala perikanan terubuk. Berkala Perikanan Terubuk, 38(2):21-40.

Noviana, P. et al. (2014). Pengaruh pemberian probiotik dalam pakan buatan terhadap tingkat konsumsi pakan dan pertumbuhan benih ikan nila (oreochromis niloticus). Journal of Aquaculture Management and Technology, 3(4):183-190.

Pereira, L., Riquelme, T., and Hosokawa, H. (2007). Effect of three photoperiod regimes on the growth and mortality of the japanese abalone haliotis discus hannai ino. Journal of Shellfish Research, 26(3):763-768.

Pratama, M. A. et al. (2015). Pengaruh berbagai rasio e/p pakan berkadar protein $30 \%$ terhadap efisiensi pemanfaatan pakan dan pertumbuhan ikan mas (cyprinus carpio). Journal of Aquaculture Management and Technology, 4(4):74-81.

Purwati, H. H. and Fitriliyani, $H$. (2016). Pengaruh penambahan vitamin c dan ekstrak temulawak pada pakan komersil terhadap pertumbuhan post larva ikan papuyu (anabas testudineus bloch). Fish scientiae (Jurnal Ilmu-Ilmu Perikanan dan Kelautan), pages 60-72.

Puspitasari, D. (2018). Efektivitas suplemen herbal terhadap pertumbuhan dan kululushidupan benih ikan lele (clarias sp.). Jurnal Ilman: Jurnal Ilmu Manajemen, 5(1).

Tacon, A. G. (1987). The nutrition and feeding of farmed fish and shrimp; a training manual. 1: The essential nutrients.

Takeuchi, T. (1988). Laboratory workchemical evaluation of dietary nutrients. Fish nutrition and mariculture, pages 179-226.

Wong, S.-L., Gao, L.-H., Chang, C.C., and Cheng, W. (2013). The effect of hot-water extract of sargassum cristaefolium on growth, innate immune responses and resistance of grouper, epinephelus coiodes. J. Fish. Soc, 40(1):11-26. 
